\title{
MANAJEMEN EVALUASIPENDIDIKAN ISLAM DI STAIN KUDUS
}

\author{
Kisbiyanto \\ STAIN Kudus, Jawa Tengah, Indonesia \\ kisbiyanto@gmail.com
}

\begin{abstract}
Abstrak
Pencapaian tujuan pendidikan Itu diukur melalui evaluasi pendidikan. Evaluasi merupakan salah satu faktor penting dalam pembelajaran. Dalam penelitian ini, tujuan yang ingin dicapai adalah mengetahui manajemen evaluasi pendidikan agama islam yang ada di STAIN Kudus. Penelitian kualitatif ini mengolah data atau dokumen yang ada di STAIN Kudus. Hasil penelitian menunjukkan bahwa STAIN Kudus memiliki banyak prosedur untuk mengevaluasi kompetensi mahasiswa, baik test, non-test, presentasi makalah dan penelitian lapangan. Ada banyak jenis mata kuliah, baik mata kuliah yang bersifat teoritis dan praktis. Mahasiswa akan lulus memperoleh nilai 2.00 akan lulus, kecuali Praktik Profesi Lapangan (PPL) yang menjadi mata kuliah utama. Mahasiswa akan lulus mata kuliah PPL jika memperoleh nilai minimal 3.49.
\end{abstract}

Kata kunci: manajemen, evaluasi, STAIN kudus

\begin{abstract}
EVALUATION MANAGEMENT OF ISLAMIC EDUCATION STUDY IN STAIN KUDUS. The attainment of education purpose is measured by education evaluation. The evaluation is one of important factors in teaching and learning process. In this research, the purpose is knowing the evaluation management of islamic education in State Islamic College of Kudus (STAIN Kudus). This qualitative research
\end{abstract}


Kisbiyanto

showed that STAIN Kudus has many procedures to evaluate students' competence, whether it is test, non test, paper presentation and field research. There are various subjects, both theoritical and practical subject. many procedures standard to evaluate the competence of students, namely test and non-test, and also presentasion of papers and field research. There are many subject matters, both of theoritical and practical subject. Students who get 2.00 will pass, except practice of teaching as a main prophetic subject, they will pass with more condition, such as 3.49 .

Keywords: management, evaluation, STAIN Kudus

\section{A. Pendahuluan}

Pendidikan mempunyai tujuan yang jelas untuk dicapai. Pencapaian tujuan pendidikan itu diukur dengan suatu alat yang bernama evaluasi pendidikan. Evaluasi merupakan salah satu faktor penting dalam pembelajaran, posisinya setara dengan menetapkan tujuan dan melaksanakan proses belajar. Sebab pencapaian kompetensi dan efektifitas proses belajar hanya dapat diketahui jika dilakukan penilaian yang komprehensif dan akurat. Evaluasi dapat diartikan sebagai penilaian, yakni merupakan salah satu kegiatan utama yang harus dilakukan oleh seorang guru dalam kegiatan pembelajaran. Dengan evaluasi, guru akan mengetahui perkembangan hasil belajar, intelegensi, bakat khusus, minat, hubungan sosial, sikap dan kepribadian peserta didik (Saleh, 2005: 1-5).

Pengembangan alat evaluasi merupakan bagian integral dalam pengembangan sistem pembelajaran (Sumiati, 2008: 200). Dalam pemilihan alat evaluasi, seorang guru harus dapat memilih dan menggunakannya dengan tepat agar hasil evaluasi dapat dipertanggungjawabkan. Dalam melaksanakan evaluasi terhadap suatu kegiatan pembelajaran, tentu tak lepas dari alat evaluasi yang harus disesuaikan dengan apa yang hendak dinilai. Alat evaluasi tersebut mempunyai beberapa karakteristik tertentu. Tidak semua alat evaluasi mempunyai karakteristik alat evaluasi yang sama.

Dalam penelitian ini, penulis akan mengkaji manajemen evaluasi pendidikan Islam yang ada di STAIN Kudus dengan menggunakan analisis data/dokumen yang ada di STAIN Kudus dan digunakan sebagai pedoman pelaksanaan perkuliahan. 


\section{B. Pembahasan}

Pendidikan dalam Islam mempuyai konsep tersendiri, yang spesifik sebagai pendidikan berbasis al-Qur'an dan sunnah. Pendidikan mempunyai nilai dari aspek pengertiannya, yaitu at-tarbiyah, at-ta'lim, dan at-ta'dib. Para pakar pendidikan Islam memberikan menjelasan yang beraragam namun mempunyai titik temu bahwa pendidikan Islam pada hakekatnya mempunyai banyak makna. Pendidikan Islam disebut al-tarbiyah yang berasal dari kata rabb (Nizar, 2002: 26). Kata-kata tersebut mempunyai makna pada pengertian dasarnya yang menunjukkan makna tumbuh, berkembang, memelihara, merawat, mengatur, dan menjaga kelestarian atau eksistensinya. Kata al-tarbiyah berasal dari tiga kata, yaitu: rabbayarbu yang berarti bertambah, tumbuh, dan berkembang (QS. Ar Ruum/30: 39), lalu kata rabiya-yarba berarti menjadi besar, dan kata rabba-yarubbu berarti memperbaiki, menguasai urusan, menuntun, dan memelihara. Kata rabb sebagaimana yang terdapat dalam QS. Al Fatihah/1: 2 (alhamdu li Allahi rabb al-alamin) mempunyai kandungan makna yang berkonotasi dengan istilah al-Tarbiyah. Sebab kata rabb (Tuhan) dan murabbi (pendidik) berasal dari akar kata yang sama. Berdasarkan hal ini, maka Allah adalah Pendidik Yang Maha Agung bagi seluruh alam semesta.

Menurut Roqib (2009: 14) pendidikan dalam bahasa Arab biasa disebut dengan istilah tarbiyah yang berasal dari kata kerja rabba, sedang pengajaran dalam bahasa Arab disebut dengan ta'lim yang berasal dari kata kerja 'allama. Pendidikan Islam sama dengan Tarbiyah Islamiyah. Kata rabba beserta cabangnya banyak dijumpai dalam Al-Qur'an, misalnya dalam QS. Al-Isra' [17]:24 dan QS. AsySyu'ara' [26]:18, sedang kata 'allama antara lain terdapat dalam QS. al-Baqarah [2]:31 dan QS. an-Naml [27]:16. Tarbiyah sering juga disebut ta'dib seperti sabda Nabi Saw.: addabani rabbifa ahsana ta'dibi (Tuhanku telah mendidikku, maka pendidikanku menjadi baik).

Pendidikan yang dalam bahasa Arab disebut tarbiyah itu merupakan derivasi dari kata rabb seperti dinyatakan dalam QS. Fatihah [1]:2, Allah sebagai Tuhan semesta alam (rabb al-'alamin), yaitu Tuhan yang mengatur dan mendidik seluruh alam. Allah memberikan informasi tentang arti penting perencanaan, penertiban, 
dan peningkatan kualitas alam. Manusia diharapkan selalu memuji kepada Tuhan yang mendidik alam semesta karenanya manusia juga harus terdidik agar memiliki kemampuan untuk memahami alam yang telah dididik oleh Allah sekaligus mampu mendekatkan diri kepada Allah Sang Pendidik Sejati. Sebagai makhluk Tuhan, manusia idealnya melakukan internalisasi secara kontinu (istiqamah) terhadap nilai-nilai ilahiyah agar mencapai derajat insan kamil (manusia paripurna) sesuai dengan kehendak Allah SWT (Roqib 2009: 14).

Nilai konsep tentang pendidikan Islam itu sendiri teramat luas jangkauannya karena menyangkut berbagai bidang yang berkaitan dengannya, mulai dari pengertian, dasar, tujuan, pendidik, subyek didik, alat-alat, kurikukum, pendekatan dan metode, lingkungan sampai pada lembaga pendidikan. Oleh karena itu, dalam buku ini penulis hanya akan membahasnya secara singkat dengan lebih memberikan titik tekan pada fungsi edukasi masjid sebagai pusat pendidikan dan pemberdayaan (Roqib, 2009: 4). Penggunaan term al-tarbiyah untuk menunjuk makna pendidikan Islam dapat dipahami dengan merujuk firman Allah, yaitu : "Dan rendahkanlah dirimu terhadap mereka berdua dengan penuh kesayangan dan ucapkanlah: "Wahai Tuhanku, kasihilah mereka keduanya, sebagaimana mereka berdua telah mendidik aku waktu kecil” (QS. Al Isra' 17: 24). Uraian di atas, secara filosofis mengisyaratkan bahwa proses pendidikan Islam adalah bersumber pada pendidikan yang diberikan Allah sebagai "pendidik" seluruh ciptaan-Nya, termasuk manusia. Dalam konteks yang luas, pengertian pendidikan Islam yang dikandung dalam term al-tarbiyah terdiri atas empat unsur pendekatan, yaitu: (1) memelihara dan menjaga fitrah anak didik menjelang dewasa (baligh). (2) mengembangkan seluruh potensi menuju kesempurnaan. (3) mengarahkan seluruh fitrah menuju kesempurnaan. melaksanakan pendidikan secara bertahap (Nizar, 2002: 26).

\section{Lingkup Pendidikan Islam}

Islam adalah suatu sistem yang memungkinkan seseorang (peserta didik) dapat mengarahkan kehidupannya sesuai dengan ideologi Islam. Melalui pendekatan ini, ia akan dapat dengan mudah membentuk kehidupan dirinya sesuai dengan nilai-nilai ajaran Islam yang diyakininya. 
Pendidikan dalam konteks ini terkait dengan gerak dinamis, positif, dan kontinu setiap individu menuju idealitas kehidupan manusia agar mendapatkan nilai terpuji. Aktivitas individu tersebut meliputi pengembangan kecerdasan pikir (rasio, kognitif), dzikir (afektif, rasa, hati, spiritual), dan keterampilan fisik (psikomotorik) (Roqib 2009: 14). Ilmu pendidikan berisi tentang teori pendidikan sekaligus data dan penjelasan yang mendukung teori tersebut. Dengan demikian, ilmu pendidikan Islam adalah teori-teori kependidikan yang didasarkan pada konsep dasar Islam yang diambil dari penelaahan terhadap Al-Qur'an, hadits, dan teori keilmuan lain, yang ditelaah dan dikonstruksi secara integratif oleh intelektual ('alim) muslim untuk menjadi sebuah bangunan teori-teori kependidikan yang bisa dipertanggungjawabkan secara ilmiah (Roqib 2009: 15). Jadi, pada hakikatnya, pendidikan Islam adalah suatu proses yang berlangsung secara kontiniu dan berkesinambungan. Berdasarkan hal ini, maka tugas dan fungsi yang perlu diemban oleh pendidikan Islam adalah pendidikan manusia seutuhnya dan berlangsung sepanjang hayat. Konsep ini bermakna bahwa tugas dan fungsi pendidikan memiliki sasaran pada peserta didik yang senantiasa tumbuh dan berkembang secra dinamis, mulai dari kandungan sampai akhir hayatnya. Secara umum tugas pendidikan Islam adalah membimbing dan mengarahkan pertumbuhan dan perkembangan peserta didik dari tahap ke tahap kehidupannya sampai mencapai titik kemampuan optimal. Sementara fungsinya adalah menyediakan fasilitas yang dapat memungkinkan tugas pendidikan berjalan dengan lancar (Nizar 2002: 32).

Konsep pendidikan Islam mencakup kehidupan manusia seutuhnya, tidak hanya memperhatikan dan mementingkan segi akidah (keyakinan), ibadah (ritual), dan akhlak (norma-etika) saja, tetapi jauh lebih luas dan dalam daripada semua itu. Para pendidik Islam umumnya memiliki pandangan yang sama bahwa pendidikan Islam mencakup berbagai bidang: (1) keagamaan, (2) akidah dan amaliah, (3) akhlak dan budi pekerti dan (4) fisik-biologis, eksak, mental-psikis, dan kesehatan . Dari sisi akhlak, pendidikan Islam harus dikembangkan dengan didukung oleh ilmu-ilmu lain yang terkait (Roqib, 2009: 22).

Dari penjelasan didepan maka dapat dinyatakan bahwa ruang 
lingkup pendidikan Islam meliputi:

a. Setiap proses perubahan menuju ke arah kemajuan dan perkembangan berdasarkan ruh ajaran Islam.

b. Perpaduan antara pendidikan jasmani, akal (intelektual), mental, perasaan (emosi), dan rohani (spiritual).

c. Keseimbangan antara jasmani-rohani, keimanan-ketakwaan, pikir-dzikir, ilmiah-alamiah, materiil-spiritual, individualsosial, dam dunia-akhirat.

d. Realisasi dwi fungsi manusia, yaitu fungsi peribadatan sebagai hamba Allah ('abdullah) untuk menghambakan diri sematamata kepada Allah dan fungsi kekhalifahan sebagai khalifah Allah (khalifatullah) yang diberi tugas untuk menguasai, memelihara, memanfaatkan, melestarikan dan memakmurkan alam semesta (rahmatan lil 'alamin) (Roqib, 2009: 22).

Suatu lembaga pendidikan sangat erat kaitannya dengan sistem nilai. Lembaga pendidikan mempunyai subyek-subyek pelaku dan penyelenggara pendidikan yang terdiri dari person-person berbeda sikap dan perilakunya. Bahkan dalam suatu lembaga pendidikan, sering kali ditemukan perbedaan itu berujung pada konflik antar individu maupun konflik antar kelompok dalam organisasi. Karena itu, untuk diperlukan suatu sistem nilai tertentu yang menjadi landasan norma interaksional antara subyek pendidikan baik kepala sekolah, guru, murid, orang tua/wali, anggota komite sekolah dan masyarakat terkait lainnya.Sebagai misal, pendidikan di Negara Kesatuan RI diselenggarakan untuk mencapai tujuan bagi pencerdasan manusia. Karena itu ada sistem nilai tertentu yang menjadi rumusan tujuan pendidikan nasional, misalnya nilai kegamaan, nilai demokratis, nilai keterbukaan, nilai penghargaan kepada sesama, nilai nasionalisme dan semacamnya.

\section{Alat Evaluasi Pendidikan}

Alat adalah sesuatu yang dapat digunakan untuk mempermudah seseorang dalam melaksanakan tugas atau mencapai tujuan secara lebih efektif dan efisien. Untuk memperjelas pengertian "alat", terapkan pada dua cara mengupas kelapa, yaitu yang satu menggunakan pisau parang, yang satu lagi tidak. Tentu saja dengan pisau parang hasilnya akan lebih baik dan lebih cepat 
dilakukan dibandingkan dengan cara yang pertama (Arikunto 2013: 40). Evaluasi merupakan suatu kegiatan untuk menilai seberapa jauh program telah berjalan seperti yang telah direncanakan (Slameto 2001: 6). Dalam evaluasi, fungsi alat juga untuk memperoleh hasil yang lebih baik sesuai kenyataan yang dievaluasi. Contohnya, jika yang dievaluasi suatu ketrampilan membaca, maka hasil evaluasinya berupa gambaran tentang tingkat ketrampilan siswa dalam membaca tersebut. Alat evaluasi dikatakan baik apabila mampu mengevaluasi sesuatu dengan hasil seperti keadaan yang dievaluasi.

Secara garis besar, alat evaluasi digolongkan menjadi dua macam yaitu, tes dan non tes. Selanjutnya tes dan non tes juga disebut teknik evaluasi.

\section{a. Teknik non tes}

Yang tergolong teknik non tes adalah:

1) Skala bertingkat (rating scale) yaitu skala yang menggambarkan suatu nilai yang berbentuk angka terhadap suatu hasil perkembangan. Contoh : kecenderungan seseorang terhadap jenis kesenian tertentu.

2) Kuesioner. Kuesioner juga sering dkenal dengan nama angket. Pada dasarnya, kuesioner adalah berupa daftar pertanyaan yang harus diisi oleh seseorang yang akan diukur (responden).

3) Daftar cocok (chek list) adalah deretan pernyataan (yang biasanya singkat), dimana responden yang dievaluasi tinggal membubuhkan tanda cocok $(\sqrt{ })$ di tempat yang sudah disediakan.

4) Wawancara (interview) adalah suatu metode atau cara yang digunakan untuk mendapatkan jawaban dari responden dengan jalan tanya jawab sepihak.

5) Pengamatan (observasi) adalah suatu teknik yang dilakukan dengan cara mengadakan pengamatan secara teliti serta pencatatan secara sistematis.

Riwayat hidup adalah gambaran tentang keadaan seseorang selama dalam masa kehidupannya. Dengan mempelajari riwayat hidup maka subyek evaluasi akan dapat menarik suatu kesimpulan tentang kepribadian, kebiasaan, dan sikap dari obyek yang dinilai. 
Kisbiyanto

\section{b. Teknik tes}

Tes adalah penilaian yang komprehensif terhadap sorang individu atau keseluruhan usaha evaluasi program. Ditinjau dari segi kegunaan untuk mengukur siswa, maka tes dibedakan atas tiga macam, yaitu: (1) tes diagnostik adalah tes yang digunakan untuk mengetahui kelemahan siswa sehingga berdasarkan hal itu dapat dilakukan pemberian yang tepat, (2) Tes formatif dimaksudkan untuk mengetahui sejauh mana siswa telah terbentuk setelah mengikuti suatu program tertentu, (3) Tes sumatif; tes sumatif dilaksanakan setelah berakhirnya pemberian sekelompok program atau sebuah program yang lebih besar (Arikunto, 2003: 41-53).

Mengenai karakteristik alat evaluasi, bahwa tidak ada satupun alat evaluasi yang serba cocok untuk segala hal. Setiap alat evaluasi mempunyai keungggulan dan kelemahannya. Secara garis besar alat evaluasi non tes cocok untuk mengukur kawasan afektif dan performance, sedangkan tes cocok untuk mengukur aspek kognitif (Slameto, 2001: 136). Sedangkan menurut Sudiyono (2006: 93-97), setidak-tidaknya ada sebelas karakteristik yang harus dimiliki oleh alat evaluasi hasil belajar, sehingga evaluasi tersebut dapat dinyatakan sebagai evaluasi yang baik, yaitu:

1) Valid

Karakteristik pertama dari hasil evaluasi yang baik adalah bahwa tes/evaluasi hasil belajar tersebut bersifat valid atau memiliki validitas. Kata valid sering diartikan dengan: tepat, benar, shahih, absah. Apabila kata valid itu dikaitkan dengan fungsi tes sebagai alat pengukur, maka sebuah tes dikatakan valid apabila tes tersebut dengan secara tepat, secara benar, secara shahih, atau secara absah dapat mengukur apa yang seharusnya diukur. Jadi hasil tes belajar dapat dinyatakan valid apabila tes hasil belajar tersebut (sebagai alat pengukur keberhasilan belajar peserta didik) dengan secara tepat, benar, shahih, atau absah telah dapat mengukur atau mengungkap hasil-hasil belajar yang telah dicapai oleh peserta didik setelah mereka menempuh proses belajar mengajar dalam jangka watu tertentu (Sudiyono, 2006: 93). Contoh: untuk mengukur tingkat partisipasi siswa dalam proses pembelajaran, bukan diukur melalui skor nilai yang diperoleh pada waktu ulangan saja tetapi dilihat melalui 
kehadiran, terpusatnya perhatian pada pelajaran, dan ketepatan menjawab pertanyaan-pertanyaan yang diajukan guru dalam arti relevan pada permasalahannya.

Nilai yang diperoleh pada waktu ulangan, bukan menggambarkan partisipasi, tetapi menggambarkan pada prestasi belajar (Widoyoko, 2013: 98-99). Menurut Sudjana (2009: 12) validitas suatu alat ukur dapat ditinjau dari berbagai segi, antara lain validitas isi (content validity), validitas konstruk (construct validity), validitas ramalan (predictive validity), dan validitas kesamaan (concurrent validity).

\section{a) Validitas isi (content validity)}

Validitas isi berkenaan dengan kesanggupan alat penilaian dalam mengukur isi yang seharusnya, artinya tes tersebut mampu mengungkapkan isi suatu konsep atau variabel yang hendak diukur. Untuk tes hasil belajar, aspek validitas yang paling penting adalah validitas isi. Yang dimaksud validitas isi adalah ukuran yang menunjukkan sejauhmana skor dalam tes berhubungan dengan penguasaan peserta tes dalam bidang studi yang diuji melalui perangkat tes tersebut. Untuk mengetahui validitas isi tes, diperlukan adanya penilaian ahli yang menguasai bidang studi tersebut. Jadi bersifat analisis kualitatif. Orang yang tidak menguasai isi bidang studi yang dites tentu saja tidak dapat melakukan penilaian tentang isi tes.

b) Validitas konstruk (construct validity)

Validitas konstruk (construct validity) atau validitas bangun pengertian berkenaan dengan kesanggupan alat penilaian untuk mengukur pengertian-pengertian yang terkandung dalam materi yang diukurnya. Pengertianpengertian yang terkandung dalam konsep kemampuan, minat, sikap dalam berbagai bidang kajian harus jelas apa yang hendak diukurnya. Konsep-konsep tersebut masih abstrak, memerlukan penjabaran yang masih spesifik sehingga mudah diukur. Ini berarti setiap konsep harus dikembangkan indikator-indikatornya. Dengan adanya indikator dari setiap 
konsep, bangun pengertian akan tampak sehingga mudah dalam menetapkan alat penilaiannya. Apabila hasil tes menunjukkan indikator-indikator yang tidak berhubungan secara positif satu sama lain, berarti ukuran tersebut tidak memiliki validitas bangun pengertian. Atas dasar itu maka indikatornya perlu ditinjau dan diperbaiki kembali.

Cara lain untuk menetapkan validitas bangun pengertian suatu alat penilaian adalah menghubungkan (korelasi) alat penilaian yang dibuat dengan alat penilaian yang sudah baku (standardized) seandainya telah ada yang baku. Bila menunjukan koefisien korelasi yang tinggi, maka alat penilaian tersebut memenuhi validitasnya.

c) Validitas ramalan (predictive validity)

Memprediksi artinya meramal, dengan meramal selalu mengenai hal yang akan datang, jadi sekarang belum terjadi. Sebuah tes bisa dikatakan memiliki validitas ramalan apabila mempunyai kemampuan untuk meramalkan apa yang akan terjadi pada masa yang akan datang. Misalnya tes masuk perguruan tinggi adalah sebuah tes yang diperkirakan mampu meramalkan keberhasilan peserta tes dalam mengikuti kuliah di masa yang akan datang. Calon yang tersaring berdasarkan hasil tes diharapkan mencerminkan tinggi rendahnya kemampuan mengikuti kuliah. Jika nilai tesnya tinggi tentu menjamin keberhasilannya kelak. Sebaliknya jika tidak lulus tes karena memiliki nilai tes yang rendah diperkirakan akan tidak mampu mengikuti perkuliahan yang akan datang (Arikunto, 2005: 69).

Validitas ramalan ini mengandung dua makna, yang pertama validitas jangka pendek dan yang kedua validitas jangka panjang. Validitas jangka pendek berarti daya ramal alat penilaian tersebut hanya untuk masa yang tidak lama, artinya skor tersebut berkorelasi pada waktu yang sama. Misalnya ketetapan (reability) terjadi pada semester dua, artinya daya ramal berlaku pada semester dua dan belum tentu terjadi pada semester berikutnya. Sedangakan validitas jangka panjang mengandung makna skor tersebut akan berkorelasi 
juga pada kemudian hari. Mengingat validitas ini lebih menekankan adanya korelasi, maka faktor yang berkenaan dengan persyaratan terjadinya korelasi harus dipenuhi. Faktor tersebut antara lain hubungan dari konsep dan variabel dapat dijelaskan berdasarkan pengetahuan ilmiah, minimal masuk akal dan tidak mengada-ada. Validitas isi dan validitas bangun pengertian mutlak diperlukan dan bisa diupayakan tanpa melakukan pengujian secara statistik (Sudjana, 2009: 15).

d) Validitas kesamaan (councurrent validity)

Validitas kesamaan suatu tes artinya membuat tes yang memiliki persamaan dengan tes sejenis yang telah ada atau yang telah dibakukan. Kesamaan tes terlingkupnya abilitas yang diukurnya, sasaran atau objek yang diukurnya, serta waktu yang diperlukan. Validitas kesamaan suatu tes adalah melalui indeks korelasi berdasarkan perhitungan korelasi. Apabila menunjukkan indeks korelasi yang cukup tinggi, berarti tes yang disusun tersebut memiliki validitas kesamaan. Untuk mudahnya kita bisa mengasusmsikan soal-soal ujian nasional dalam bidang studi tertentu sebagai tes baku sehingga dapat digunakan sebagai acuan dalam penyusunan bidang studi sejenis. Dengan demikian guru dapat membuat tes bidang studi tersebut yang memiliki kesamaan dengan tes pada ujian nasional bidang studi yang sama dengan uji korelasi.

Dilain pihaksekolah atau guru dapat membuat tes baku dalam bidang-bidang studi tertentu. Melalui beberapa kali uji coba kemudian hasilnya dianalisis tingkat kesukaran dan daya pembedanya disamping diuji validitas dan reabilitasnya, berdasarkan uji coba tersebut item tes diperbaiki dan disempurnakan sehingga menghasilkan tes yang mendekati kebakuan. Tes ini nantinya dapat digunakan sebagai acuan bagi penyusunan tes sejenis melalui uji validitas kesamaan (Sudjana, 2009: 15-16).

2) Reliabel

Kata reliabilitas sering diterjemahkan dengan stability (=keajegan) atau consistency (= kemantapan). Reliabel artinya suatu 
alat ukur dapat dikatakan reliabel atau handal jika ia mempunyai hasil yang taat asas (consistent). Misalnya, suatu alat ukur diberikan kepada sekelompok peserta didik saat ini, kemudian diberikan lagi kepada sekelompok peserta didik yang sama pada saat yang akan datang, dan ternyata hasilnya sama atau mendekati sama, maka dapat dikatakan alat ukur tersebut mempunyai tingkat reliabilitas yang tinggi (Arifin, 2014).

Apabila istilah tersebut dikaitkan fungsi tes sebagai alat pengukur mengenai keberhasilan belajar peserta didik, maka sebuah tes hasil belajar dapat dikatakan reliabel apabila hasil-hasil pengukuran yang dilakukan dengan tes tersebut secara berulang kali terhadap subyek yang sama, senantiasa menunjukkan hasil yang sama atau sifatnya ajeg dan stabil. Dengan demikian suatu ujian dikatan telah memiliki reabilitas (daya keajegan mengukur) apabila skor-skor atau nilai-nilai yang diperoleh para peserta ujian untuk pekerjaan ujiannya adalah stabil kapan saja-dimana saja dan oleh siapa saja ujian itu dilaksanakan, diperiksa dan dinilai.

Reabilitas suatu instrumen alat ukur berdasarkan cara memperoleh data dapat digolongkan menjadi tiga yaitu: konsistensi internal, stabilitas dan antarpenilai (Mardapi 2012: 52). Bila hasilhasil yang diperoleh selalu sama (setidak-tidaknya mendekati sama), maka dapat dikatakan bahwa alat pengukur berupa tes tersebut telah memiliki reabilitas yang tinggi. Prinsip reabilitas menghendaki adanya keajegan dari hasil pengukuran yang berulang-ulang terhadap seorang subyek atau sekelompok subyek yang sama, dengan catatan bahwa subyek-subyek yang diukur itu tidak mengalami perubahanperubahan (Sudiyono, 2006: 95).

Ajeg atau tetap tidak selalu harus sama, tetapi mengikuti perubahan secara ajeg. Jika keadaan A mula-mula lebih rendah dibandingkan dengan $\mathrm{B}$, maka jika diadakan pengukuran ulang, si A tetap lebih rendah dari B. Itulah yang dikatakan ajeg atau tetap, yaitu tetap dalam kedudukan siswa di antara anggota kelompok yang lain. Jika dihubungkan dengan validitas maka validitas berhubungan dengan ketepatan sedangkan reliabilitas berhubungan dengan ketetapan atau keajegan (Widoyoko 2013: 100). 
3) Obyektif

Obyektif berarti tidak adanya unsur pribadi yang mempengaruhinya. Sebuah tes hasil belajar dapat dikatakan sebagai tes hasil belajar yang obyektif, apabila tes tersebut disusun dan dilaksanakan "menurut apa adanya". Ditinjau dari segi isi atau materi tesnya, maka istilah "apa adanya" itu mengandung pengertian bahwa materi tes tersebut adalah diambilkan atau bersumber dari materi atau bahan pelajaran yang telah diberikan sesuai atau sejalan dengan tujuan instruksional khusus yang telah ditentukan. Bahan pelajaran yang telah diberikan atau diperintahkan untuk dipelajari oleh peserta didik itulah yang dijadikan acuan dalam pembuatan atau penyusunan tes hasil belajar tersebut. Dilihat dari segi pemberian skor atau penentuan nilai hasil tesnya, maka istilah "apa adanya" itu terkandung pengertian bahwa pekerjaan koreksi, pemberian skor dan penentuan nilainya terhindari dari unsur-unsur subyektifitas yang melekat pada diri penyusun tes (Sudiyono, 2006: 96).

Ada dua faktor yang mempengaruhi subyektivitas dari suatu tes, yaitu bentuk tes dan penilai. Bentuk tes uraian akan member banyak kemungkinan kepada penilai untuk memberikan penilaian menurut caranya tersendiri. Dengan demikian maka hasil dari seorang siswa yang mengerjakan soal dari sebuah tes, akan memperoleh skor yang berbeda apabila dinilai oleh dua orang. Itulah sebabnya pada waktu sekarang ini ada kecenderungan penggunaan tes oyektif di berbagai bidang. Untuk menghindari unsur subyektifitas dari penilai, maka sistem skoringnya dapat dilakukan dengan sebaik-baiknya, antara lain dengan membuat pedoman scoring terlebih dahulu.

Subyektifitas dari penilai akan dapat masuk secara lebih leluasa terutama pada tes bentuk uraian. Faktor-faktor yang mempengarui subyektifitas penilai antara lain : kesan penilai terhadap siswa (hallo effect), bentuk tulisan, gaya bahasa yang digunakan peserta tes, waktu mengadakan penilaian, kelelahan dan sebagainya. Untuk mengurangi masuknya unsur subyektivitas dalam penilaian, maka penilaian harus dilaksanakan:

1) Secara continue (terus menerus) sehingga akan diperoleh gambaran yang lebih jelas tentang keadaan siswa. Tes yang diadakan secara on the spot dan hanya satu kali (one shot) atau 
dua kali, tidak akan dapat memberikan hasil yang obyektif tentang keadaan siswa. Kalau misalnya ada seorang anak yang sebetulnya pandai, tetapi pada waktu guru mengadakan tes dia sedangdalam kondisi yang jelek, maka kemungkinan nilai tesnya juga jelek. Hal ini tidak menggambarkan kemampuan anak yang sebenarnya,

2) Secara komprehensif (menyeluruh), yaitu mencakup keseluruhan materi, mencakup berbagai aspek berpikir (ingatan, pemahaman, analisis, aplikasi dan sebagainya) dan melalui berbagai cara, yaitu tes tertulis, tes lisan, tes perbuatan, pengamatan dan sebagainya (Widoyoko, 2013: 100).

4) Praktis

Karakteristik keempat dari hasil tes yang baik adalah bahwa tes hasil belajar tersebut bersifat practicability (praktis) dan ekonomis. Bersifat praktis mengandung pengertian bahwa tes hasil belajar tersebut dapat dilaksanakan dengan mudah, karena tes itu: (1) bersifat sederhana, dalam arti tidak perlu memerlukan peralatan yang banyak atau peralatan yang sulit pengadaannya dan (2) lengkap, dalam arti bahwa tes tersebut dilengkapi dengan petunjuk mengenai cara mengerjakannya, kunci jawabannya dan pedoman scoring serta penentuan nilainya.

Praktis artinya mudah digunakan. Jika alat ukur itu sudah memenuhi syarat tetapi sukar digunakan, berarti tidak praktis. Kepraktisan ini bukan hanya dilihat dari pembuat alat ukur (guru), tetapi juga bagi orang lain yang ingin menggunakan alat ukur tersebut.

Sedangkan bersifat ekonomis mengandung pengertian bahwa tes hasil belajar tersebut tidak memakan waktu panjang dan tidak memerlukan tenaga serta biaya yang banyak (Sudiyono, 2006: 97). Selain empat karakteristik alat evaluasi sebagaimana yang dipaparkan diatas, alat evaluasi juga mempunyai karakteristik sebagai berikut :

5) Relevan

Relevan artinya alat ukur yang digunakan harus sesuai dengan standar kompetensi, kompetensi dasar, dan indikator yang telah ditetapkan. Alat ukur juga harus sesuai dengan domain hasil belajar, seperti domain kognitif, afektif, dan psikomotor. Jangan sampai ingin 
mengukur domain kognitif menggunakan alat ukur non-tes. Hal ini tentu tidak relevan.

6) Representatif

Representatif artinya materi alat ukur harus betul-betul mewakili dari seluruh materi yang disampaikan. Hal ini dapat dilakukan bila guru menggunakan silabus sebagai acuan pemilihan materi tes. Guru juga harus memperhatikan proses seleksi materi, mana materi yang bersifat aplikatif dan mana yang tidak, mana yang penting dan mana yang tidak.

7) Deskriminatif

Deskriminatif artinya adalah alat ukur itu harus disusun sedemikian rupa, sehingga dapat menunjukkan perbedaan-perbedaan yang sekecil apapun. Semakin baik suatu alat ukur, maka semakin mampu alat ukur tersebut menunjukkan perbedaan secara teliti. Untuk mengetahui apakah suatu alat ukur cukup deskriminatif atau tidak, biasanya didasarkan atas uji daya pembeda alat ukur tersebut.

8) Spesifik

Spesifik artinya suatu alat ukur disusun dan digunakan khusus untuk objek yang diukur. Jika alat ukur tersebut menggunakan tes, maka jawaban tes jangan menimbulkan ambivalensi atau spekulasi.

9) Proporsional

Proporsional artinya suatu alat ukur harus memiliki tingkat kesulitan yang proporsional antara sulit, sedang dan mudah. Begitu juga ketika menentukan jenis alat ukur, baik tes maupun non-tes.

10) Taraf Kesukaran

Instrumen yang baik terdiri atas butir-butir instrumen atau alat penilaian yang tidak terlalu mudah dan tidak terlalu sukar. Butir soal yang terlalu mudah tidak mampu merangsang audience mempertinggi usaha memecahkannya dan sebaliknya kalau terlalu sukar membuat audience putus asa serta tidak memiliki semangat untuk mencoba lagi karena di luar jangkauannya. Di dalam istilah evaluasi index kesukaran ini diberi simbol $\mathrm{p}$ yang dinyatakan dengan "Proporsi".

11) Daya Pembeda

Daya pembeda sebuah instrumen adalah kemampuan 
instrumen tersebut membedakan antara audience yang pandai (berkemampuan tinggi) dengan audience yang tidak pandai (berkemampuan rendah). Indek daya pembeda ini disingkat dengan $\mathrm{D}$ dan dinyatakan dengan Index Diskriminasi.

\section{Evaluasi Pendidikan di STAIN Kudus}

Pelaksanaan pembelajaran di Sekolah Tinggi Agama Islam Negeri Kudus mempunyai kekhususan pada mata kuliah tingkat perguruan tinggi, misalnya untuk rumpun mata kuliah praktikum sebanyak delapan yang diajarkan secara berurutan dari semester pertama hingga semester delapan. Urutannya, semester ke-1 praktikum bahasa Arab, semester ke-2 praktikum bahasa Inggris, semester ke-3 praktikum tahfidz, semester ke-4 praktikum ibadah, semester ke-5 praktik kerja lapangan (PKL), semester ke-6 praktikum profesi/micro teaching/micro counseling/micro bank, dan semacamnya sesuai program studi, semester ke-7 praktik profesi lapangan (PPL), dan semester ke-8 kuliah kerja nyata (KKN). Semua program studi dan jurusan mengajarkan semua mata kuliah tersebut. Selain itu, ada mata kuliah tingkat jurusan dan tingkat program studi yang spesifik sesuai dengan keilmuan dan keterampilan masing-masing. Pedoman akademik Sekolah Tinggi Agama Islam Negeri Kudus menjelaskan bahwa evaluasi sebagai alat pengukuran keberhasilan dan kelulusan mata kuliah di Sekolah Tinggi Agama Islam Negeri Kudus mengacu pada tata pembelajaran dan evaluasi di STAIN Kudus. Evaluasi kelulusan tiap mata kuliah ditentukan minimal nilai 2.00, kecuali mata kuliah Praktik Profesi Lapangan (PPL) harus mencapai nilai minimal 3,49, dengan pedoman sebagai berikut:

1) Penilaian hasil belajar dinyatakan dengan $A, B, C, D$ dan $E$ yang masing-masing bernilai 4, 3, 2, 1 dan 0.

2) Penilaian hasil belajar mahasiswa dapat dilaksanakan dengan:

a. Sistem Penilaian Acuan Patokan (PAP) yang lebih ditujukan untuk mengetahui kemampuan mahasiswa dalam penguasaan materi kuliah.

b. Sistem Penilaian Acuan Norma (PAN) yang lebih ditujukan untuk memperoleh gambaran mengenai 
kedudukan mahasiswa dalam kelas/kelompoknya.

c. Pada permulaan kuliah dosen wajib memberitahukan sistem yang akan dipakai dalam penilaian.

d. Apabila dosen menggunakan Penilaian Acuan Patokan (PAP) maka sejak kuliah pertama kali dosen wajib memberitahukan patokan nilai yang menggambarkan penguasaan materi kuliah yang dituntut.

e. Apabila dosen menggunakan Penilaian Acuan Norma (PAN) maka yang harus diperhatikan adalah :

1. Jumlah mahasiswa paling sedikit 30 orang.

2. Prestasi mahasiswa diukur nisbi, terhadap prestasi pukul rata dari kelasnya dengan menghitung simpang baku (standart deviation).

3. Atas dasar pretasi kelas pukul rata dan simpang baku ditentukan prestasi mahasiswa dengan huruf A, B, C, $\mathrm{D}$ dan $\mathrm{E}$.

f. Tata cara dan pedoman penilaian yang lebih rinci diatur sendiri oleh masing-masing jurusan.

3) Cara Penilaian

a. Nilai mata kuliah adalah perpaduan antara nilai Tes Tengah Semester (TTS) dan nilai Tes Akhir Semester (KT), Tes Sisipan (TS) dan Karya Tulis (KT).

b. Skor akhir merupakan Nilai Pukul Rata (NIPURA) dari berbagai nilai tes dengan pembulatan : kurang dari 0,05 dibulatkan ke bawah, dan 0,05 atau lebih di bulatkan ke atas.

c. Sesudah terdapat nilai akhir baru dituangkan dalam bentuk Nilai skala 0-4 serta huruf dan distribusi PAN adalah sebagai berikut dengan predikat A (nilai 81100), predikat A- (nilai 79-80), predikat $\mathrm{B}+$ (nilai 7576), predikat B (nilai 70-74), predikat C+ (nilai 65-69), predikat C (nilai 56-64), dan predikat D dan E kurang dari nilai 56 berarti tidak lulus.

d. Cara penilaian ujian praktek/praktikum/skripsi diatur secara tersendiri.

4) Perhitungan Indeks Prestasi

a. Indeks Prestasi (IP) adalah nilai kredit rata-rata yang 
merupakan satuan nilai akhir yang menggambarkan mutu penyelesaian suatu program pendidikan.

b. Indeks Prestasi dihitung pada setiap akhir semester yang hasilnya disebut IP semester dan pada akhir program pendidikan hasilnya disebut IP Kumulatif (IPK).

c. Cara menghitung Indeks Prestasi ialah jumlah kredit mata kuliah yang diperoleh dikalikan dengan nilai masing-masing mata kuliah, dibagi dengan jumlah kredit mata kuliah yang diambil (dicoba). Rumus perhitungan IP adalah nilai kredit yang diperoleh dibagi jumlah kredit yang diambil/dicoba.

5) Ujian Ulang

a. Mahasiswa yang gagal dalam suatu ujian mata kuliah, harus mengulang kuliah dan ujian pada semester lain.

b. Kode untuk mata kuliah ulangan diberi tanda (U) dalam Kartu Studi Tetap.

6) Peringatan dan Sanksi

a. Ketua Jurusan wajib menyerahkan kepada Dosen Pembim-bing Akademik daftar mahasiswa yang perlu mendapat peringatan/perlu dikeluarkan.

b. Dosen Pembimbing Akademik wajib memperingatkan mahasiswa yang IP-nya antara 1,3 - 1,9.

c. Mahasiswa yang IP-nya 1,3 ke bawah diperingatkan oleh Ketua atas usul Ketua Jurusan/Pembantu Ketua I, dan tembusannya disampaikan kepada Dosen Pembimbing Akademik dan orang tua/wali.

d. Mahasiswa yang sudah diperingatkan dan sampai 4 semester tidak dapat meningkatkan IP-nya sampai batas ketetapan minimal, tidak diperkenankan melanjutkan studinya.

e. Surat pengeluaran mahasiswa diterbitkan oleh Ketua atas usul Ketua Jurusan/Pembantu Ketua I, yang tembusannya disampaikan kepada Dosen Pembimbning Akademik dan orang tua/wali mahasiswa.

f. Mahasiswa juga dapat dikeluarkan (DO) karena :

1) Melebihi batas waktu studi yang ditentukan

2) Sebab-sebab lain yang termasuk pelanggaran tata 
tertib yang telah ditentukan.

g. Mahasiswa dapat dikenakan sanksi berupa peringatan, atau tidak diperkenankan mengikuti kegiatan akademik apabila terbukti melakukan pelanggaran terhadap peraturan tata tertib dan ketentuan administrasi yang berlaku.

7) Penilaian hasil belajar total terdiri dari dua tahap, yakni penilaian belajar total tahap pertama dan tahap kedua.

8) Penilaian hasil belajar total tahap pertama dilaksanakan pada semester IV. Hasil penilaian ini dipakai untuk menentukan apakah mahasiswa diperbolehkan mengikuti kuliah di STAIN atau tidak Mahasiswa yang dinyatakan berhak mengikuti/ melanjutkan kuliah di STAIN semester IV adalah mereka yang telah mengumpulkan sekurang-kurangnya 40 sks dengan IPK 2, dihitung dari nilai yang terbaik.

9) Penilaian hasil belajar total tahap kedua dilaksanakan pada akhir program, dan digunakan untuk menentukan yudisium mahasiswa apakah ia dinyatakan lulus sebagai sarjana STAIN atau tidak. Mahasiswa yang dapat dinyatakan sebagai Sarjana S.1 STAIN adalah apabila :

a. Telah memperoleh kredit yang dibebankan antara 144160 sks dengan IPK minimal 2.

b. Tidak ada nilai E.

c. Untuk nilai mata kuliah Pancasila, Bahasa Arab, Praktikum, Skripsi dan beberapa mata kuliah tertentu yang ditentukan oleh Jurusan sekurang-kurangnya adalah C.

d. Untuk Mata Kuliah tertentu yang disayaratkan dengan kelulusan minimal C masing-masing Jurusan ditentukan oleh kebijakan jurusan.

10) Predikat kelulusan Sarjana S.1 STAIN dinyatakan dalam Indeks Prestasi Kumulatif (IPK) yang diperoleh dalam satu program dinyatakan sebagai berikut : cumlaude (nilai 3,5 4,00), amat baik (nilai 3,00-3,49), baik (nilai 2,50-2,99), dan cukup (nilai 2,00-2,49). 
Kisbiyanto

\section{Simpulan}

Berdasarkan analisis di poin sebelumnya, hasil penelitian menunjukkan bahwa STAIN Kudus memiliki banyak prosedur untuk mengevaluasi kompetensi mahasiswa, baik test, non-test, presentasi makalah dan penelitian lapangan. Ada banyak jenis mata kuliah, baik mata kuliah yang bersifat teoritis dan praktis. Mahasiswa akan lulus memperoleh nilai 2.00 akan lulus, kecuali Praktik Profesi Lapangan (PPL) yang menjadi mata kuliah utama. Mahasiswa akan lulus mata kuliah PPL jika memperoleh nilai minimal 3.49. 


\section{DAFTAR PUSTAKA}

Arifin, Zainal. 2014. Karakteristik Alat Evaluasi Pembelajaran, diposkan oleh Hana Lutfi, diunduh pada tanggal 27 Pebruari 2014.

Arikunto, Suharsimi. 2005. Dasar-Dasar Evaluasi Pendidikan (edisi kedua). Jakarta:Bumi Aksara.

Mardapi, Djemari. 2012. Pengukuran, Penilaian dan Evaluasi Pendidikan. Yogyakarta: Nuha Medika.

Nizar, Samsul. 2002. Filsafat Pendidikan Islam Pendekatan Historis, Teoritis, dan Praktis. Jakarta: Ciputat Press.

Pedoman Akademik Civitas Akademika STAIN Kudus. 2013.

Rofiq, Moh. 2009. Ilmu Pendidikan Islam Pengembangan Pendidikan Integratif di Sekolah, Keluarga, dan Masyarakat. Yogyakarta: LKiS.

Shaleh, Abdul Rachman. 2005. Panduan Evaluasi Hasil Belajar. Jakarta: Majelis Pertimbangan dan Pemberdayaan Pendidikan Agama dan Keagamaan.

Slameto. 2001. Evaluasi Pendidikan. Jakarta: Bumi Aksara.

Sudiyono, Anas. 2006. Pengantar Evaluasi Pendidikan. Jakarta: PT. Raja Grafindo Persada.

Sudjana, Nana. 2009. Penilaian Hasil Proses Belajar Mengajar. Bandung: PT. Remaja Rosdakarya.

Sumiati dan Asra. 2008. Metode Pembelajaran. Bandung: Wacana Prima.

Widoyoko, Eko Putro. 2013. Evaluasi Program Pembelajaran. Yogyakarta: Pustaka Pelajar. 
Kisbiyanto

halaman ini bukan sengaja dikosongkan 